DOI dx.doi.org/10.24866/7444-4707-6/250-264

Ю.А. Колесникова, В.А. Семаль, О.В. Нестерова, Н.А. Сакара, М.А. Бовсун

\title{
ВЛИЯНИЕ БИОУГЛЯ НА ЭМИССИЮ ЗАКИСИ АЗОТА ИЗ АГРОПОЧВ ЮГА ПРИМОРСКОГО КРАЯ
}

К 2012 году численность населения мира достигла 7 миллиардов и, согласно результатам математического моделирования, к 2050 году она превысит 9 миллиардов [14]. Для обеспечения продовольствием всего человечества потребуется увеличить текущую урожайность примерно на $70 \%$ во всем мире и почти на $100 \%$ в развивающихся странах [24]. Чтобы удовлетворить растущий спрос на продукты питания, нужно улучшать продуктивность почвы с помощью агротехнических приёмов [4].

Для повышения урожайности в почву вносят азотные, фосфорные и калийные удобрения. За последние 50 лет использование органических и минеральных азотных удобрений во всем мире увеличилось почти в 9 раз [15]. Однако большая часть удобрений не поглощается растениями, а вымывается в грунтовые воды или испаряются в атмосферу [13]. Так, около 30\% внесенных азотных удобрений улетучиваются из почвы в виде соединений закиси азота [10], это усиливает естественный парниковый эффект и может привести к дополнительному потеплению поверхности Земли и оказать неблагоприятное воздействие на природные экосистемы и человечество.

Одним из актуальных и экологичных решений проблемы глобального потепления стало применение биоугля (биочара) как уникального почвенного мелиоранта, позволяющего, с одной стороны, улучшить эффективность удобрений, а с другой стороны - снизить эмиссию парниковых газов.

За последние несколько десятилетий опубликовано множество научных работ, посвященных проблеме глобального потепления. Научное сообщество ищет разные способы уменьшения выбросов парниковых газов. Среди этих газов сильнее всего на озоновый слой действует закись азота, которая мощнее углекислого газа в 310 раз [30].

\footnotetext{
Благодарность. Работа выполнена при финансовой поддержке РФФИ (№ 19-2905166).
} 
Источником закиси азота являются в большей степени агропочвы. Так, за 2017 год агропочвами всего мира в атмосферу было выброшено 79\% закиси азота из общего потока этого газа [11]. Поэтому актуальным вопросом является разработка агротехнологий, уменьшающих эмиссию парниковых газов из почвы и одним из решений, по мнению многих ученых, является внесение биоугля в почву.

Производство закиси азота в почве в основном представляет собой микробный процесс, при котором нитрификаторы в аэробных условиях окисляют NH4+, а денитрификаторы восстанавливают NO3- в анаэробных условиях [9]. Влияние биочара на поток N2O в почве может зависеть от влажности почвы: так, при низкой влажности почвы (менее 80\% влаги), в аэробных условиях биочар может увеличить поток $\mathrm{N} 2 \mathrm{O}$, так как будет служить дополнительным источником азота для нитрификации. Но в условиях высокой влажности почвы (>80\%), где процесс денитрификации преобладает над нитрификацией, биоуголь будет, напротив, уменьшать выбросы N2O из почвы, способствуя полному протеканию процесса денитрификациии с выделением N2 [19].

Интенсивность нитрификации и денитрификации в сельскохозяйственных землях и эмиссия азота зависят от многих факторов, определяющихся не только типом почв, но и разнообразием почвенной микрофлоры, влажностью, водным и воздушным режимом почв, а также соотношением углерода и общего азота, аммонийных и нитратных форм азота [2, 3, 31].

Некоторые исследователи $[17,31]$ предполагают, что биоуголь снижает эмиссию закиси азота, изменяя активность микроорганизмовнитрификаторов и денитрификаторов, другой возможной причиной уменьшения потоков закиси азота является иммобилизация биоуглем микробных ферментов.

Снижение содержания минерального азота (NH4+-N) после внесения биоугля в почву является основной причиной снижения выбросов $\mathrm{N} 2 \mathrm{O}$ [22]. Эмиссия закиси азота коррелирует с активностью почвенной уреазы, а биочар за счёт понижения кислотности почвы (повышения значений $\mathrm{pH}$ ) оказывает на уреазу лимитирующее воздействие и снижает поток закиси азота из почвы [28].

Различия в эффекте биоугля на эмиссию закиси азота связаны с его исходным материалом и технологией производства. Биоуголь, изготовленный при температуре $350 \mathrm{oC}$, значительно уменьшает эмиссию закиси азота 
по сравнению с тем, который был получен при температуре 550oC [12]. Биочар, подвергнутый пиролизу при температуре ниже $350^{\circ} \mathrm{C}$, оказывает слабое и незначительное воздействие на выбросы $\mathrm{N} 2 \mathrm{O}$ из почвы, это можно объяснить его более слабой ароматической структурой и меньшей площадью поверхности, которые обеспечивают меньший потенциал взаимодействия с N2O [21].

Биоуголь имеет особую высокопористую структуру, которая определяет не только величину площади удельной поверхности биоугля и скорость межфазных взаимодействий, но и благоприятно влияет на жизнедеятельность микроорганизмов [16].

Высокая порозность биоугля обеспечивает ему высокие сорбционные свойства. Биоуголь способен поглощать воду, масса которой превышает его собственный вес. Отдельные фракции биоугля способны поглощать воду массой в 3 раза превышающую вес биоугля [18].

Важным фактором снижения эмиссии закиси азота из почв является дозировка биоугля. Лу с соавторами [20] после двухлетнего полевого опыта подтвердили положительное действие биоугля на эмиссию закиси азота. В своём эксперименте они использовали биоуголь из бамбуковых листьев, изготовленный при температуре 500оС. В первый год опыта эмиссия закиси азота снизилась на $14.3 \%, 21.0 \%$ и $28.2 \%$ с биоуглем в дозах 2,5 и 10 т/га, соответственно, но во второй год эффект от биоугля не наблюдался. Лучший эффект на потоки закиси азота оказала наибольшая доза внесения биочара (10 т/га). Во многих исследованиях было отмечено, что при увеличении дозы внесения биоугля уменьшаются выбросы $\mathrm{N} 2 \mathrm{O}$, это отношение наблюдалось при добавлении в почву биоугля в дозе до 40 т/га [19].

Наряду со свойствами самого биоугля важно учитывать и параметры почвы. Установлено, что при внесении биочара в кислые почвы поток закиси азота не изменяется. Рекомендуется вносить биоуголь в почву с реакцией среды близкой к нейтральной [8]. Гранулометрический состав почвы тоже имеет значение при использовании биоугля: в суглинистых почвах наиболее сильно проявляется снижение биочаром потока закиси азота [26]. Вероятно, это связано с тем, что суглинистые почвы имеют больше капиллярных пор внутри агрегатов, чем песчаные или глинистые почвы, тем самым более плотно удерживая почвенную воду.

В некоторых работах отмечается корреляция температуры почвы и потоков закиси азота независимо от дозы внесения биоугля. С уменьше- 
нием температуры почвы сокращаются выбросы закиси азота [20, 29]. Интересным является то, что в полевых условиях влажность почвы не влияет на эмиссию газов [20].

Но результаты, полученные учёными из разных стран, далеко не однозначны. В некоторых исследованиях наблюдалось повышение выбросов закиси азота из-за ускорения процесса нитрификации [25].

На сегодняшний день нет разработанной системы внесения биоугля, которая бы учитывала и свойства биоугля, и параметры почвы, а также всю совокупность внешних факторов. Также отслеживается недостаток длительных исследований, позволяющих оценить действие биоугля в почве с течением времени.

Таким образом, необходимо проведение длительных многофакторных полевых опытов с внесенным биоуглём, изучение которых расширит понимание почвенных процессов и дополнит мировую базу знаний о влиянии внесенного в почву биоугля на эмиссию газов.

Впервые было исследовано влияние внесенного в почву биоугля на эмиссию закиси азота из агропочв Приморского края на примере агротемногумусовых подбелов, характеризующихся тяжёлым гранулометрическим составом и высокой плотностью сложения. В этих почвах в весеннее и летнее время происходит застой влаги, что способствует увеличению эмиссии парниковых газов, эмиссию увеличивает и интенсивное применение удобрений, часть из которых улетучивается в атмосферу.

Целью исследования стало изучение влияния внесенного в почву биоугля (биочара) на эмиссию закиси азота из агротемногумусовых подбелов юга Приморского края в зависимости от: разных доз биоугля

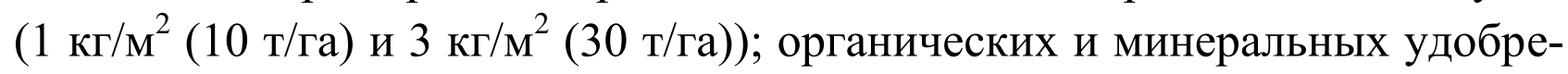
ний; наличия или отсутствия дренажной мелиоративной системы.

Полевой опыт проводился на территории Приморской овощной опытной станции - филиала ФГБНУ «ФНЦ овощеводства» $\left(43^{\circ} 25^{\prime} 22.4 " \mathrm{~N}\right.$ $132^{\circ} 18^{\prime} 50.6 " \mathrm{E}$, с. Суражевка, Приморский край, Россия). Почвы Приморского края формируются под влиянием муссонного климата: зимой они испытывают глубокое промерзание; весной - позднее оттаивание, пересыхание поверхностных горизонтов над еще мерзлыми слоями; летом - длительное переувлажнение водами муссонных дождей в условиях высоких температур; осенью - просыхание. Среднесуточная температура на иссле- 
дуемой площадке в течение экспериментального периода (июль, август, сентябрь, октябрь 2018 года) составляла $19.530 \mathrm{C}$, а среднесуточная влажность воздуха $-78.6 \%$.

Почвы представлены агротемногумусовыми подбелами [6] на делювиальных отложениях глинистых сланцев или Endoargic Anthrosols (Endoclayic) по World Reference Base for Soil Resources [27]. Почвы характеризуются тяжёлым гранулометрическим составом, низкой гумусированностью и избыточным переувлажнением [23].

На одном из опытных участков имеется глубинный дренаж, который представлял собой систему прокладываемых на глубине (120 см) дренажных труб (дрен), уложенных по всему периметру осушаемого участка.

Эксперимент с внесением биоугля (производства компании «Красилов и К», произведенный из древесных остатков березы Betula alba методом пиролиза при температуре 360 - 3800С) в дозах 1 кг/м2 и 3 кг/м2 в пахотный (0 - 29 см) горизонт почвы был заложен в июне 2018 г.

Содержание углерода в биоугле составляло 95.663\%, зольность - 4.1 $6.4 \%$ в зависимости от размера фракции биоугля, а значения летучих элементов в пределах от $23.5 \%$ до $26.9 \%, \mathrm{pH}-8.09$. Концентрация кальция, натрия и магния 17.7, 5.7 и 4.2 мг/кг сухой массы биоугля соответственно [1].

Измерения эмиссии закиси азота начались через месяц после внесения биочара (июль) и затем проводились каждые две недели до конца октября 2018 года.

В агротемногумусовых подбелах гранулометрический состав пахотного горизонта изменяется от суглинка тяжелого до глины легкой, по кислотности он относится к слабокислым и близким к нейтральной в верхнем пахотном горизонте, по содержанию углерода поверхностные горизонты исследуемых почв слабогумусированы. Основным профилеобразующим процессом является лессиваж.

Эмиссия $\mathrm{N}_{2} \mathrm{O}$ из почвы определялась на пятигазовом анализаторе G2508 (Picarro). Для каждого варианта эксперимента были взяты четыре повторения, а повторение включало три образца почвы. Алюминиевые бюксы с почвой помещались в закрытую стеклянную камеру объемом 1 литр. Эмиссия газа измерялась в течение 300 секунд (полученные данные позволяют судить о потоках закиси азота из почвы), после полученная информация соотносилась с температурой, давлением и влажностью воздуха в лаборатории и на поле в ходе эксперимента. 
Используя данные об эмиссии, были рассчитаны кумулятивные (накопленные) потоки газа (мг N2O-N/M²*час) и среднее квадратичное отклонение $\left(\mathrm{R}^{2}\right)$, позволяющее оценить достоверность полученных результатов.

Через месяц после внесения биоугля в почву были получены положительные результаты, показывающие снижение эмиссии закиси азота: при добавлении биоугля в почву в дозе 1 кг/м² эмиссия закиси азота уменьшилась на $52.2 \%$, а в дозе 3 кг/м2 - на 97.8\% по сравнению с контролем. Предположительно, биоуголь является ингибитором денитрификации, действие которого проявляется в повышении пористости и аэрации почвы. Наилуч-

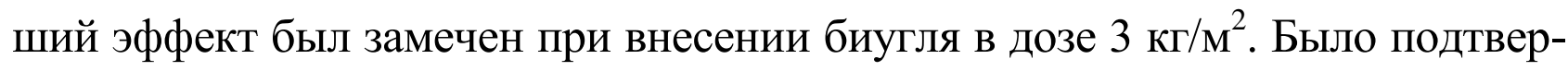
ждено раннее высказанное другими учёными предположение о том, что эмиссия закиси азота снижается по мере увеличения дозы биочара.

Сравнение кумулятивных потоков $\mathrm{N}_{2} \mathrm{O}$ в различное время исследования не позволяет сделать однозначный вывод о динамике действия биоугля (рис. 1). Во второй месяц после внесения биоугля потоки резко падают и далее продолжают снижаться вплоть до конца октября. Снижение потоков связано с выносом азота из почвы капустой, растущей на поле эксперимента и требующей большого количества питательных элементов в период роста верхушечной почки [7]. Анализ биомассы капусты не выявил превышений по количеству нитратов и нитритов.

В начале августа наблюдалось уменьшение потоков закиси азота с

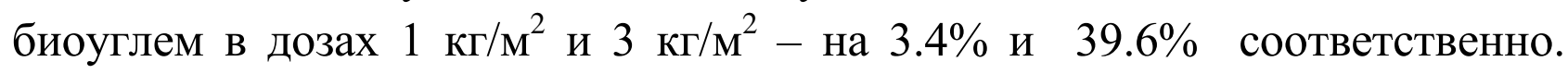
В конце августа потоки $\mathrm{N}_{2} \mathrm{O}$ в вариантах с биоуглём оказались больше, чем в контроле (на 17.8 и 15.4\%). В сентябре биоуголь снизил поток газа на 90\% независимо от его количества. В октябре заметный эффект оказал биоуголь в

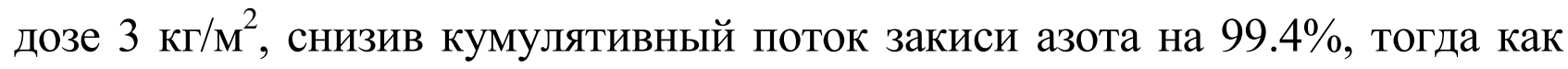
биоуголь в меньшей дозе - всего на $68.1 \%$ по сравнению с контролем.

В целом, можно утверждать о существовании накопительного действия биоугля, поскольку потоки закиси азота с биоуглем в любых дозах продолжали с течением времени уменьшаться. Таким образом, первоначальный поток закиси азота (13.07.2018 г.) с биоуглем в дозе 1 кг/м ${ }^{2}$ на момент завершения опыта (25.10.2018 г.) уменьшился в 142 раза, а с биоуглем в дозе $3 \kappa г / \mathrm{M}^{2}-$ в 238 раз.

Колоссальные изменения потоков газа связаны не только с действием биоугля во времени, но и с сезонными изменениями микробной актив- 
ности, циркуляции воздуха, выпадением осадков и других внешних явлений, влияние которых ещё необходимо выяснить.

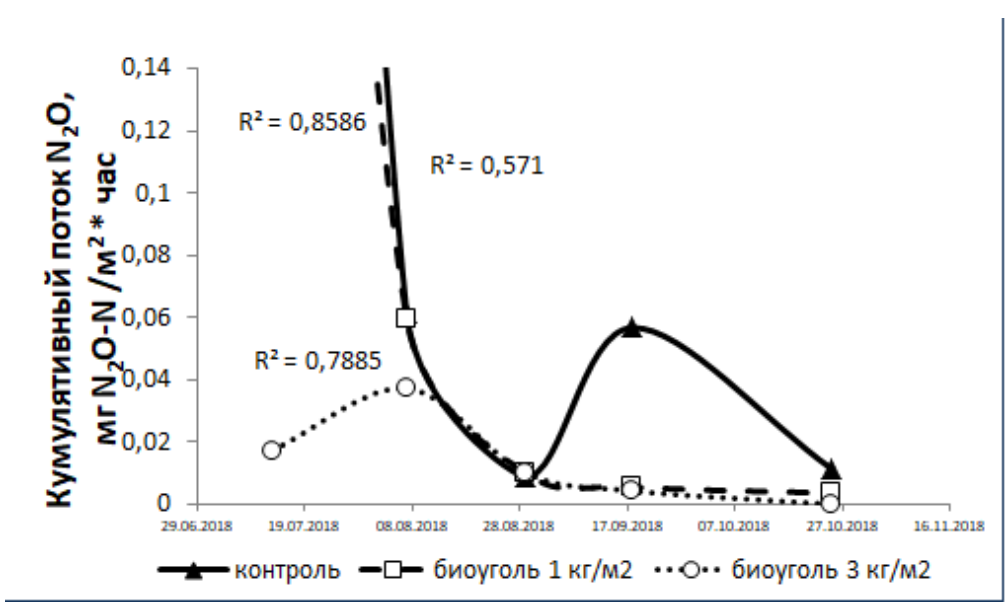

Puc. 1. Кумулятивный поток $\mathrm{N}_{2} \mathrm{O}$ из агротемногумусового подбела в течение четырех месяцев измерений

Несмотря на кажущуюся очевидной проблему ускорения глобального потепления, производство и использование удобрений в сельском хозяйстве неуклонно растёт, а вместе с ними увеличивается вынос удобрений в атмосферу и гидросферу.

Проводилось исследование влияния минеральных и органических удобрений на эмиссию и кумулятивный поток закиси азота из агротемногумусового подбела в течение 4 месяцев. После месяца действия биоугля не было замечено особенных изменений в эмиссии закиси азота, но, тем не менее, можно отметить тенденцию, что с переходом от меньшей дозы биоугля к большей наблюдается уменьшение эмиссии.

В первом месяце исследования (13.07.2018 г.) наблюдалось уменьшение потока закиси азота с минеральными удобрениями и биоуглем в

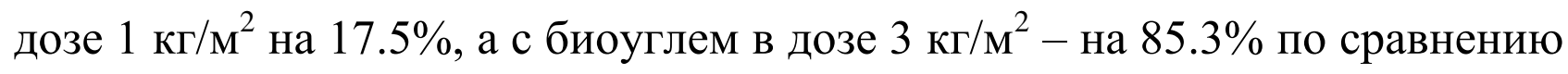
с контролем (рис. 2). Резкое повышение кумулятивных потоков в начале августа (7.08.2018 г.) в контрольном варианте может быть связано с растворением азотных удобрений дождевыми осадками и их активное улетучивание, тогда как в других вариантах биоуголь, возможно, поглотил азотные удобрения и препятствовал их испарению.

В конце августа (29.08.2018 г.) больший поток был зафиксирован из почвы, в которую вносились минеральные удобрения и биоуголь в дозе

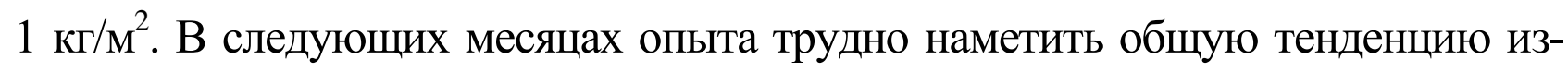


менения потоков закиси азота с минеральными удобрениями. В сентябре из общей массы набора данных снова выбивается поток биоугля в дозе 1 кг/ $\mathrm{m}^{2}$, а потоки из контроля и варианта с биоуглем в дозе 3 кг/ $\mathrm{M}^{2}$ примерно равнозначны. В октябре выбросы закиси азота в варианте с минеральными удобрениями и биоуглем в большой дозе были выше, чем в остальных вариантах опыта.

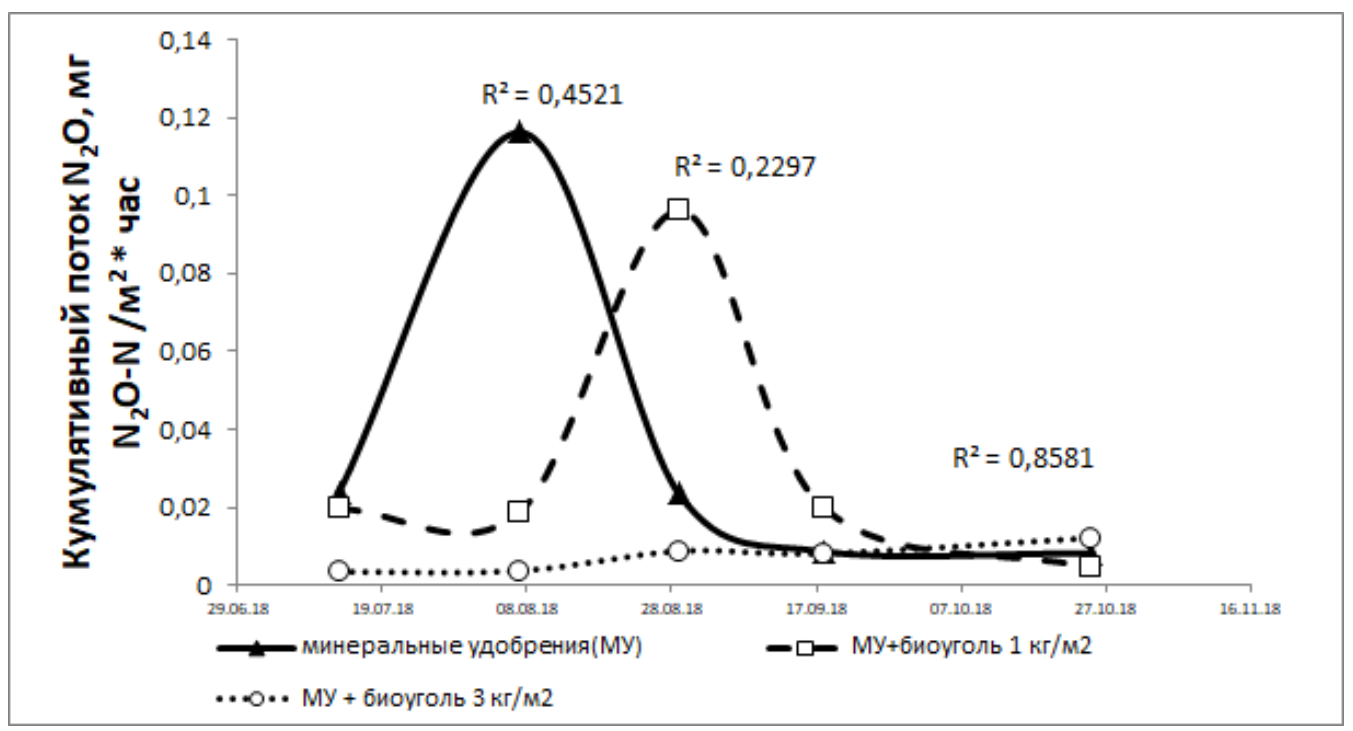

Puc. 2. Кумулятивный поток $\mathrm{N}_{2} \mathrm{O}$ из агротемногумусового подбела

с минеральными удобрениями и биоуглем в течение четырех месяцев измерений

Таким образом, виден положительный первоначальный эффект биоугля на эмиссию и поток закиси азота из почвы с минеральными удобрениями. Однако влияние это длится непродолжительное время и можно заметить отсутствие какого-либо значимого эффекта внесения биоугля в почву на выбросы закиси азота во второй половине эксперимента.

Внесение органических удобрений благоприятно влияет на почву, увеличивая содержание белкового азота и микробную активность и, вследствие этого, значительно повышает интенсивность разложения азота. В качестве органического удобрения был использован "Гигантин” из куриного помёта $\left(1.25 \mathrm{\kappa} / \mathrm{M}^{2}\right)$.

Экспериментальные данные показали, что потоки закиси азота в варианте с органическими удобрениями в среднем в 5 раз меньше, чем в варианте с минеральными удобрениями, так как часть удобрений вымывается из почвы поверхностным и внутрипочвенным стоком. Через месяц после внесения биоугля и "Гигантина" не было обнаружено значительных колебаний значений в эмиссии закиси азота из почвы разных вариантов, но была выявлена тенденция к увеличению в контрольном варианте (рис. 3). 
В первый месяц после внесения (13.07.2018г.) биоуголь в дозе

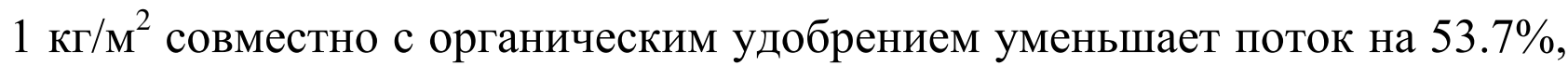

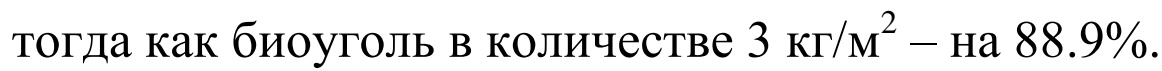

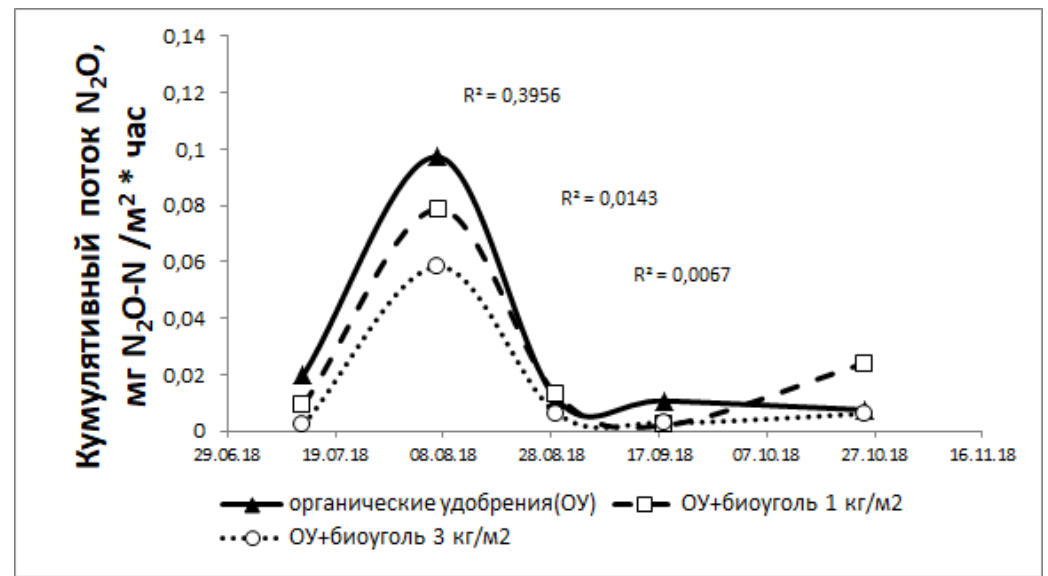

Puc. 3. Кумулятивный поток $\mathrm{N}_{2} \mathrm{O}$ из агротемногумусового подбела с органическими удобрениями и биоуглем в течение четырех месяцев измерений

В начале второго месяца можно заметить резкое увеличение всех потоков, что может объясняться усилением микробной активности вследствие повышения температуры воздуха и почвы из-за воздействия юговосточных тропических циклонов, которые преобладают в Приморском крае во второй половине лета.

В начале августа (7.08.2018 г.) потоки закиси азота с биоуглем в дозе

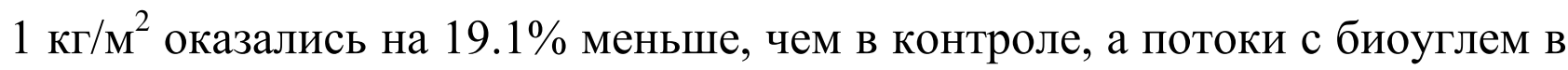
дозе 3 кг $/ \mathrm{m}^{2}$ - на 40.0\% меньше. Как видно, действие биоугля уже на второй месяц эксперимента начинает уменьшаться. В конце августа, сентябре и октябре эмиссия закиси азота снижается. Это может быть связано с выносом азота капустой или с постепенным снижением микробной активности в период наступающего осенью похолодания.

Во второй половине опыта вариант с биоуглем в дозе 1 кг/м ${ }^{2}$ показывает неоднозначные результаты: в конце августа кумулятивные потоки закиси азота растут, затем в сентябре падают, но в октябре снова растут, в то время как биоуголь в дозе 3 кг/м² продолжает снижать поток закиси азота в течение всего эксперимента.

Таким образом, биоуголь в дозе 3 кг/м ${ }^{2}$ оказался наиболее эффективен в совокупности как с органическими, так и с минеральными удобрениями и может быть рекомендован к внесению в агропочвы юга Приморского края для снижения эмиссии закиси азота. 
В ходе полевого эксперимента были получены потоки закиси азота в вариантах с внесенным биоуглем в почвы без дренажной системы и с дренажем. Более легкий гранулометрический состав и низкая влажность почвы участка с дренажем способствуют созданию аэробных условий и снижению процесса денитрификации, в результате которого в атмосферу попадает закись азота. Поэтому было сделано предположение, что эмиссия закиси азота в почве без дренажа будет выше, чем в почвах с дренажем.

Через месяц после внесения биоугля было замечено, что эмиссия закиси азота в контрольном варианте и в варианте с биоуглем в дозе 1 кг/м в почвах с дренажем была значительно ниже, чем без дренажа, в то время как эмиссия из почвы с биоуглем в дозе 3 кг/ $\mathrm{m}^{2}$ на участке с дренажем не отличалась от бездренажного участка.

Известно, что под влиянием дренажа коэффициент использования азота удобрений увеличивается на 30\% [5]. Соответственно, эмиссия закиси азота из почвы с дренажем должна быть меньше, чем из почвы без дренажа, однако в эксперименте существенного различия между вариантами с дренажем и без дренажа не наблюдалось.

В контрольном варианте с органическими удобрениями и в варианте с органикой и биоуглем в дозе 3 кг/ м $^{2}$ эмиссия закиси азота в почвах без дренажа была несколько выше, чем в почвах с дренажем, а в варианте с органикой и биоуглем в дозе 1 кг/м² эмиссия оставалась приблизительно одинаковой на обоих участках.

В начале августа (7.08.2018 г.), на второй месяц эксперимента, было обнаружено увеличение эмиссии закиси азота в почвах без дренажа по сравнению с почвой с дренажной системой во всех вариантах опыта.

В конце августа (29.08.2018 г.) ситуация оказалась обратной - эмиссия в варианте без дренажа была выше, чем в варианте с дренажем за исключением варианта с минеральными удобрениями и биоуглем в дозе $1 \kappa г / \mathrm{M}^{2}$. В сентябре и октябре результаты оказались неоднозначными и сильно варьировали. В сентябре и октябре не удалось выявить какой-либо закономерности.

По результатам исследования можно сделать следующие выводы.

1. Биоуголь снижает эмиссию и кумулятивный поток закиси азота из агротемногумусовых подбелов юга Приморского края. Установлено, что биоуголь в дозе 1 кг/м $\mathrm{M}^{2}$ понизил кумулятивный поток $\mathrm{N}_{2} \mathrm{O}$ из почвы на 
$52.2 \%$, а в дозе 3 кг/ $\mathrm{M}^{2}$ - на 97.8\% за весь период эксперимента. В течение всего опыта биоуголь 3 кг/м $\mathrm{M}^{2}$ действовал эффективней меньшей дозы в

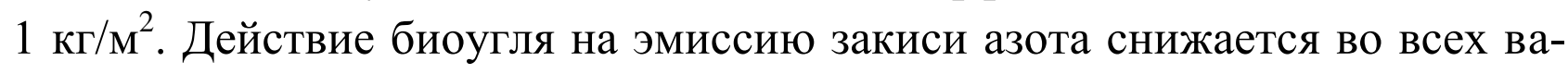
риантах опыта с течением времени.

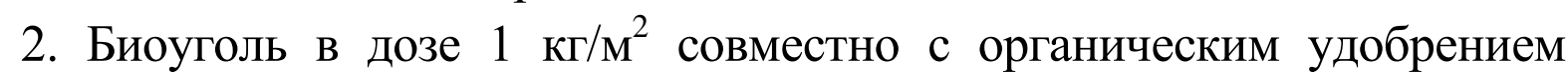
уменьшает поток закиси азота на $53.7 \%$, а в дозе 3 кг/м² - на $88.9 \%$. Через 4 месяца эмиссия закиси азота в варианте с биоуглем в дозе 1 кг/м² была выше контроля в 3 раза, а с биоуглем в дозе 3 кг/ $\mathrm{m}^{2}-$ ниже в 1,2 раза. Биоуголь в дозе 3 кг/м оказывается эффективней с органическими удобрениями.

3. Биоуголь в дозе 1 кг/м² с минеральным удобрением снизил поток закиси азота на $17.5 \%$, а биоуголь в дозе 3 кг/ $\mathrm{m}^{2}$ с минеральным удобрением на $85.3 \%$. Через 4 месяца эмиссия закиси азота с минеральным удобрением и

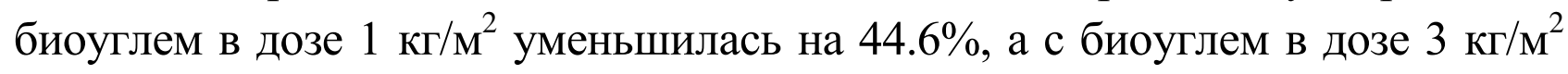
увеличилась на $47.5 \%$. Биоуголь в дозе 1 кг/м² оказывается эффективней биоугля в количестве 3 кг/м ${ }^{2}$ для снижения эмиссии закиси азота.

4. Разница в эмиссии закиси азота между почвой с дренажной системой и без неё велика только в первые два месяца после внесения биоугля. В целом, отсутствие дренажа, как и его наличие, не ограничивает внесение биоугля в почву, так как он снижает выбросы закиси азота в обоих вариантах опыта.

Для дальнейшего изучения влияния биоугля на потоки закиси азота в почве однолетнего наблюдения может быть недостаточно для предоставления научно обоснованных рекомендаций по применению биоугля в сельскохозяйственной практике Приморского края. Необходимо провести полевые испытания для наблюдения последействия применения биочара в условиях Приморского края в овощных севооборотах, наряду с изучением влияния биоугля из различного сырья, а также изучить механизмы его действия на эмиссию закиси азота, исследуя изменения почвенных бактериальных и грибных сообществ и соотношение минеральных форм азота почвы.

\section{Литература}

1. Бовсун М.А., Колесникова Ю.А., Попова А.Д., Нестерова О.В., Семаль В.А. Перспективы использования биоугля из BETULA ALBA на землях сельскохозяйственного назначения в Приморском крае // Природа без границ. XII Международный экологический форум, 18-19 октября 2018 г., Владивосток [Электронный ресурс]: сборник итоговых материа- 
лов / [отв. ред. Т.С. Вшивкова]. Электрон. дан. Владивосток: Изд-во Дальневост. федерал. ун-та, 2018. 1 CD-ROM. Систем. требов.: процессор с частотой 1,3 ГГц (Intel, AMD); оперативная память от 256 МБ, Windows (XP; Vista; 7 и т.п.). Загл. с экр. ISBN 978-5-7444-4399-3.

2. Гитарский М.Л., Романовская А.А., Карабань Р.Т., Конюшков Д.Е., Назаров И.М. Эмиссия закиси азота при использовании минеральных удобрений в России // Почвоведение. 2000. № 8. С. 943 - 950. (M.L. Gitarskii, A.A. Romanovskaya, R.T. Karaban', I.M. Nazarov, D.E. Konyushkov "Nitrous oxide emission from the use of mineral fertilizers in Russia", Eurasian Soil Science, 33 (8), 822-827 (2000)).

3. Завалин А.А., Дридигер В.К., Белобров В.П., Юдин С.А. Азот в черноземах при традиционной технологии обработки и прямом посеве (обзор) // Почвоведение. 2018. № 12. С. 1506 - 1516. (A.A. Zavalin, V.K. Dridiger, V.P. Belobrov, S.A. Yudin "Nitrogen in chernozems under traditional and direct seeding cropping systems: a review", Eurasian Soil Science. 51 (12), 1497 - 1506 (2018)). doi: 10.1134/S0032180X18120146.

4. Кудеяров В.Н. Почвенно-биогеохимические аспекты состояния земледелия в Российской Федерации // Почвоведение. 2019. № 1. С. 19 121. (Kudeyarov V.N. "Soil-biogeochemical aspects of arable farming in the Russian Federation”, Eurasian Soil Science. 52 (1), 94 - 104 (2019)). doi: 10.1134/S0032180X1901009X.

5. Митрофанов Ю.И., Анциферова О.Н., Пугачева Л.В., Карасева О.В., Пантелеева Т.Н. Роль осушения в земледелии на переувлажняемых почвах // Земледелие. 2016. № 6. С. 24 - 27.

6. Полевой определитель почв. М.: Почвенный институт им. В.В. Докучаева, 2008. 182 с.

7. Тараканов Г.И., Мухин В.Д., Шуин К.А., Борисов Н.В., Климов В.В. и др. Овощеводство: учеб. пособие. М.: КолосС, 2003. 472 с.

8. Brassard P., Godbout S., H. Palacios J., Jeanne T., Hogue R., Dubé R., Limousy L., Raghavan L. Effect of six engineered biochars on GHG emissions from two agricultural soils: A short-term incubation study // Geoderma. 2018. Vol. 327. P. 73 - 84. doi: 10.1016//j.geoderma.2018.04.022.

9. Cameron K., Di H., Moir J. Nitrogen losses from the soil/plant system: a review // Annals of Applied Biology. 2013. Vol. 162. P. 145 - 173. doi: 10.1111/aab.12014. 
10. Cui Z.L., Zhang H.Y., Chen X.P., Zhang F.S. Pursuing sustainable productivity with millions of smallholder farmers // Nature. 2018. Vol. 555. P. 363 - 366. doi: 10.1038/nature25785.

11. Environmental Protection Agency (EPA). Inventory of U.S. Greenhouse Gas Emissions and Sinks: 1990-2017 // U.S. Environmental Protection Agency. - 2017. P. 675.

12. Fiorentino N., Sánchez-Monedero M.A., Lehmann J., Enders A., Fagnano M., Cayuel M.L. Interactive priming of soil $\mathrm{N}$ transformations from combining biochar and urea inputs: A $15 \mathrm{~N}$ isotope tracer study // Soil Biology and Biochemistry. 2019. Vol. 131. P. 166 - 175. doi:10.1016/j.soilbio.2019.01.005.

13. Gao W.L., Yang H., Kou L., Li S.G. Effects of nitrogen deposition and fertilization on $\mathrm{N}$ transformations in forest soils: A review // Journal of Soils and Sediments. 2015. Vol. 15, № 4. P. 863 - 879. doi: 10.1007/s11368015-1087-5.

14. Grafton R.Q., Daugbjerg C., Qureshi M.E. Towards food security by 2050 // Food Security. 2015. Vol.7, № 2. P. 179 - 183. doi: 10.107/s12571-0150444-x.

15. Ladha J.K., Tirol-Padre A., Reddy C.K., Cassman K.G., Verma S., Powlson D.S., et al. Global nitrogen budgets in cereals: A 50-year assessment for maize, rice, and wheat production systems // Scientific Reports. 2016. Vol. 6 [19355]. doi: 10.1038/srep19355.

16. Lehmann, J., Rillig, M., Thies, J., Masiello, C., Hockaday, W., Crowley, D. Biochar effects on soil biota: A review // Soil Biology and Biochemistry. - 2011. Vol. 43. P. 1812-1836. doi: 10.1016/j.soilbio.2011.04.022.

17. Li S., Song L., Jin Y., Liu, S., Shen, Q., Zou, J. Linking N2O emission from biochar-amended composting process to the abundance of denitrify (nirK and nosZ) bacteria community // AMB Express. 2016. Vol. 6, № 37. P. 1 - 9. doi: 10.1186/s13568-016-0208-x.

18. Liang, B., Lehmann, J., Solomon, D., Sohi, S., Skjemstad, J.O., Luiza, F.J., Engelhard, M.H., Neves, E.G., Wirick, S. Stability of biomass-derived blackcarbon in soils // Geochimica et Cosmochimica Acta. 2008. Vol. 72, № 14. P. 6069 - 6078. doi: 10.1016/j.gca.2008.9.028

19. Liu Q., Zhang Y., Liu B., Amonette J.E., Lin Z., Liu G., Xie, Z. How does biochar influence soil N cycle: A meta-analysis // Plant and Soil. 2018. Vol. 426. P. 211 - 225. doi: 10.1007/s11104-018-3619-4. 
20. Lu X., Li Y., Wang H., Singh B.P., Hu S., Luo Y., Li J., Xiao Y., Cai X., Li Y. Responses of soil greenhouse gas emissions to different application rates of biochar in a subtropical Chinese chestnut plantation // Agricultural and Forest Meteorology. 2019. Vol. 271. P. 168 - 179. doi: 10.1016/j.agrformet.2019.03.001.

21. Mandal S., Sarkar B., Bolan N., Novak J., Ok Y.S., van Zwieten L., Singh B.P., Kirkham M.B., Choppala G., Spokas K., Naidu R. Designing advanced biochar products for maximizing greenhouse gas mitigation potential // Critical Reviews in Environmental Science and Technology. 2016. Vol. 46, № 17. P. 1367 - 1401. doi: 10.1080/10643389.2016.1239975.

22. Maucieri C., Zhang Y., McDaniel M.D., Borin M., Adams M.A. Short-term effects of biochar and salinity on soil greenhouse gas emissions from a semiarid Australian soil after re-wetting // Geoderma. 2017. № 307. P. 267 - 276. doi: 10.1016/j.geoderma.2017.07.028.

23. Popova A.D., Semal V.A. Biochar: sources, properties and applications // The 1st International Conference on North East Asia Biodiversity. Abstracts. Yamaika LLC. 2018. P.165.

24. Rodriguez A., Sanders I. R. The role of community and population ecology in applying mycorrhizal fungi for improved food security // ISME Journal. 2015. Vol. 9, № 5. P. 1053 - 1061. doi: 10.1038/ismej.2014.207.

25. Sánchez-García M., Roig A., Sánchez-Monedero M.A., Cayuela M.L. Biochar increases soil N2O emissions produced by nitrification-mediated pathways // Frontiers in Environmental Science. 2014. Vol. 2, № 25. P. 1 - 10. doi: 10.3389/fenvs.2014.00025.

26. Verhoeven E., Pereira E., Decock C., Suddick E., Angst T., Six J. Toward a better assessment of biochar-nitrous oxide mitigation potential at the field scale // Journal of Environmental Quality. 2017. Vol. 46, № 2. P. 237 246. doi: 10.2134/jeq2016.10.0396.

27. IUSS Working Group WRB. World Reference Base for Soil Resources. International soil classification system for naming soils and creating legends for soil maps. World Soil Resources Reports № 106. FAO, Rome, 2014.

28. Wu F., Jia Z., Wang S., Chang S.X., Startsev A. Contrasting effects of wheat straw and its biochar on greenhouse gas emissions and enzyme activities in a Chernozemic soil // Biology and Fertility of Soils. 2013. Vol. 49, № 5. P. 555 - 565. doi: 10.1007/s00374-012-0745-7. 
29. Zhang J., Peng C., Zhu Q., Xue W., Shen Y., Yang, Y.Z., Shi G.H., Shi S.W., Wang M. Temperature sensitivity of soil carbon dioxide and nitrous oxide emissions in mountain forest and meadow ecosystems in China // Atmospheric Environment. 2016. Vol. 142. P. 340 - 350. doi: 10.1016/j.atmosenv.2016.08.011.

30. Zhang A., Cheng G., Hussain Q., Zhang M., Feng H., Dyck M., et al. Contrasting effects of straw and straw-derived biochar application on net global warming potential in the loess plateau of China // Field Crops Research. 2017. Vol. 205. P. 45 - 54. doi: 10.1016/j.fcr.2017.02.00C.

31. Zhou B., Yanfang F., Yueman W., Linzhang Y., Lihong X., Baoshan $\mathrm{X}$. Impact of hydrochar on rice paddy $\mathrm{CH} 4$ and $\mathrm{N} 2 \mathrm{O}$ emissions: a comparative study with pyrochar // Chemosphere. 2018. Vol. 204. P. 474 - 482. doi: 10.1016/j.chemosphere.2018.04.056 